Tyndale Bulletin 66.1 (2015) 157-160

\title{
PARTICIPATION AND CREATION IN AUGUSTINE AND AQUINAS ${ }^{1}$
}

\author{
Yonghua Ge \\ (yge2011@gmail.com)
}

'The One and the Many' names one of the most ancient debates in philosophy-it enquires whether reality is ultimately a unity or a plurality and how the two relate if we admit to both. For most people today, this topic seems too archaic to have any relevance. However, in his Bampton Lectures at the University of Oxford in 1992, The One, the Three and the Many, Colin Gunton sought to analyze the ills of modernity-excessive secularism and radical fragmentation-in the frame of the One and the Many. He argued that the dominant mode of the Western philosophical and theological tradition tended to prioritize unity over plurality and as a result led to the revolt of the Many against the One in modern thought. On this interpretation, the origin of the modern problem lies in the failure of classical Western theologians, such as Augustine and Aquinas, in offering an adequate Christian solution to the problem of 'the One and the Many'.

In the past few decades, Gunton's thesis has generated much energy in theological discussions. However, despite the growing literature on Gunton, no substantial response has been made to his central challenges: Did Augustine and Aquinas really succumb to and perpetuate the defect of Platonism - the tendency to disparage multiplicity? Is there an adequate resolution to the modern probleman ontology in which all things are unified by the One which does not diminish but preserves the integrity of plurality? This thesis, to an extent, seeks to respond to these two key questions.

Since Gunton was convinced that the ultimate solution to problem of 'the One and the Many' must consist in ontological reconstruction on the basis of Trinitarian thought, a brief assessment of his

1 Yonghua Ge, 'The Many and the One: The Metaphysics of Participation in Connection to creatio ex nihilo in Augustine and Aquinas' ( $\mathrm{PhD}$ dissertation, Cambridge University, 2015). Supervisor: Professor J.M. Soskice. 
'Trinitarian Ontology' is made in the introduction. An analysis of the three transcendentals for his ontology-perichoresis, substantiality and relationality - suggests that his proposal is not as successful as intended. In particular, his preoccupation with horizontal relationalityinner relations within the Godhead and inter-relations between creatures-seems to have made his system deeply deficient in vertical relationality, namely creatures' ontological relationship to God. An alternative, better solution to the problem of the One and the Many, I argue, can in fact be found in the Christianized idea of participation in classical theologians such as Augustine and Aquinas, who profoundly transformed this originally Platonic concept in the light of creatio ex nihilo. The rest of this thesis, then, examines how the theories of participation in Augustine and Aquinas can help resolve the dialectic of the One and the Many.

Chapter one examines Augustine's general concept of participation and the question of unity. Although participation is one of the core ideas in Augustine's philosophical thought, little study has been carried out on his metaphysical thought of participation. Despite the continuity between Plato's idea of participation and that of Augustine, as Merconi suggests, our investigation shows that there is also a crucial discontinuity between the two. This discontinuity, I argue, was caused by the doctrine of creatio ex nihilo, which was absent in Plato but foundational to Augustine's thought. For this reason, Augustine's adoption of participation was not slavish to Platonism, as Gunton claimed; rather, standing upon the Christian tradition before him, Augustine significantly Christianized the Platonic idea of participation in the light of creatio ex nihilo. One of the crucial changes he made was to identify the One with Being, which had significant consequences for the issue of the One and the Many. One of the consequences is that absolute multiplicity—and hence absolute evildoes not exist, since insofar as something exists, it must contain unity. Another implication is that God, the Supreme Being, must be Supremely One, which leads to the concept of divine simplicity. With divine simplicity, Augustine made advances from Plato by reaching a new level of unity in his concept of participation.

Chapter two deals with the one of Gunton's central critiques of Augustine and asks whether Augustine was truly dismissive of multiplicity and materiality (an essential aspect of plurality). Gunton's criticism is based on the assumption that Augustine uncritically 
embraced the Platonic view of matter and multiplicity. However, a careful examination shows that Augustine's position on multiplicity differs significantly from that of 'the Platonists' (perhaps Neoplatonists who were Augustine's contemporaries). Particularly, guided by the truths of creation, Augustine developed a subtle but crucial distinction between multiplicity and non-simplicity, which makes multiplicity compatible with simplicity. As a result, God's simplicity is by no means exclusive of multiplicity, as in Plotinus's thought, and unity can be affirmed without degrading plurality. For this reason, contrary to Gunton, Augustine was ultimately a defender of multiplicity, as is made clear by his persistent polemic against 'the Platonists' over the goodness of the body. In fact, his dispute with the Neoplatonists reveals a fundamental divergence between two worldviews: creationism and emanationism. Augustine could not simply disparage the value of matter and multiplicity as 'the Platonists' did, since he understood that all that exists is created by God and must be intrinsically good.

Since the heart of participation is relationality, chapter three discusses Augustine's view of the relationship between the One (God) and the Many (creation). One of the difficulties of Greek philosophy lies in the dialectic of transcendence and immanence, namely that the transcendence of the Deity is often affirmed at the cost of his immanence to the world and vice versa. With the unique implications of creatio ex nihilo, Augustine however was able to overcome this dialectic by showing that only a truly transcendent God can be truly immanent to the world, which was an important contribution to the debate on the One and the Many. In the process of Christianization of participatory ontology, however, Augustine was still on the way, and for a more complete and thorough transformation of participation, we have to look at Aquinas.

Indeed, as chapter four shows, an even tighter connection between participatory ontology and creatio ex nihilo can be found in the thought of Aquinas. One of his remarkable achievements is the establishment, arguably for the first time in history, of a true metaphysics of creation, which enabled Aquinas to transform the concept of participation more fundamentally in the light of the truths of creation. In his treatment of the One, Aquinas furthered Augustine's insight on the convertibility of unity and being, which naturally leads to the conclusion that God is simple. As a key idea in Aquinas's thought, divine simplicity has been 
intensively criticised in contemporary theology and philosophy of religion. A closer analysis of the meaning and significance of divine simplicity in Aquinas, however, suggests that much of the criticism is based on misconceptions-particularly the failure to see the concept in connection to Aquinas's metaphysics of creation. For Aquinas, to affirm divine simplicity is essentially to affirm that God is the Creator of all.

Chapter five examines Aquinas's treatment of multiplicity. Moving beyond his predecessors, Aquinas developed a highly sophisticated account of the relationship between unity, division and multiplicity. By carefully distinguishing between different kinds of multiplicity, Aquinas made it clear that multiplicity is not univocal and as such things can be simultaneously 'one' and 'many'. In addition, by deontologizing divine ideas, a crucial deviation from Platonism, Aquinas showed that it is consistent for the simple God to have multiple ideas. Contrary to Gunton's accusation, therefore, Aquinas was able to move beyond the dialectic of the One and the Many.

Finally, chapter six examines relationality in Aquinas's concept of participation. Furthering Augustine's insights, Aquinas made it more explicit that God is genuinely immanent to the world because he is truly transcendent. More importantly, Aquinas was able to extend the implications of God's transcendence and immanence more deeply into his vision of reality, thus providing a firmer ontological foundation for the integrity of created realities. In Aquinas, then, we find a most thorough transformation of participatory ontology in the light of creatio ex nihilo. It can thus be argued that it is in Aquinas's metaphysics of creation and participation that we can find a most adequate solution to the problem of 'the One and the Many'.

Hence, in response to Gunton's fundamental challenges, this thesis concludes that Augustine and Aquinas were not guilty of elevating unity at the cost of plurality, as Gunton accused. Rather, by profoundly transforming participation in the light of creatio ex nihilo, those Christian thinkers, especially Aquinas, offered an ontology in which 'the One' unifies all things and yet sustains and protects 'the Many'. It can be argued therefore that a way out of the modern problematic may be found in the retrieval of the traditional Christian concept of participation, which is essentially a metaphysical expression of the foundational doctrine of creatio ex nihilo. 